\title{
Surface shortwave cloud radiative effect of cumulus and stratocumulus- cumulus cloud types in the Caribbean area (Camagüey Cuba, 2010-2016)
}

\author{
Boris BARJA ${ }^{1,2 *}$, Jorge ROSAS ${ }^{2}$, Victoria Eugenia CACHORRO ${ }^{3}$, Carlos TOLEDANO $^{3}$, \\ Juan Carlos ANTUÑA-MARRERO ${ }^{3}$, Rene ESTEVAN ${ }^{2}$ and Ángel DE FRUTOS ${ }^{3}$ \\ ${ }^{1}$ Laboratorio de Investigaciones Atmosféricas, Universidad de Magallanes, Av. Bulnes 01855, Punta Arenas, 6101042, \\ Chile. \\ ${ }^{2}$ Grupo de Óptica Atmosférica de Camagüey, Centro Meteorológico de Camagüey, km 7 1⁄2 Av. Finlay, Camagüey, \\ 70100, Cuba. \\ ${ }^{3}$ Grupo de Óptica Atmosférica (GOA-UVA), Departamento de Física Teórica, Atómica y Óptica, Facultad de Ciencias, \\ Universidad de Valladolid, Paseo de Belén 7, 47011, Valladolid, España. \\ *Corresponding author; email: bbarja@gmail.com
}

Received: March 25, 2020; accepted: June 2, 2021

\begin{abstract}
RESUMEN
Los efectos de las nubes tipo cúmulos $(\mathrm{Cu})$ y de la combinación de los tipos estratocúmulos-cúmulos $(\mathrm{Sc}-\mathrm{Cu})$ sobre la radiación solar en la superficie terrestre de Camagüey, Cuba, fueron estudiados durante seis años (de junio de 2010 a mayo de 2016). El efecto radiativo de las nubes (CRE, por su sigla en inglés) fue calculado por dos métodos. El primero $\left(\mathrm{CRE}_{\mathrm{m}}\right)$ utiliza valores de irradiancia solar medidos mediante observaciones actinométricas en condiciones de nubosidad, donde el tipo de nube es reportado de manera visual. En el segundo método $\left(\mathrm{CRE}_{0}\right)$ se calculó la irradiancia solar en la superficie, tanto en casos de nubosidad como despejados, con un modelo de transferencia radiativa 1-D, utilizando como entrada principal los valores de espesor óptico de nubes (COD) obtenidos de un fotómetro solar de AERONET. Se aplicó un criterio de correspondencia temporal entre los valores de COD y las observaciones actinométricas, con el fin de clasificar los valores de COD por tipo de nube. Al aplicar este criterio, se eliminaron los COD pertenecientes a las nubes ópticamente finas. Finalmente, se seleccionaron 255 y 732 observaciones de COD para los tipos de nubes $\mathrm{Cu}$ y Sc-Cu, respectivamente. Los resultados muestran diferencias estadísticamente significativas al nivel de confianza del $95 \%$ entre la $\mathrm{CRE}$ para $\mathrm{Sc}-\mathrm{Cu}$ y $\mathrm{Cu}$, utilizando ambos métodos. Los valores medios de $\mathrm{CRE}_{\mathrm{m}}$ y $\mathrm{CRE}_{0}$ para el tipo de nube $\mathrm{Cu}(\mathrm{Sc}-\mathrm{Cu})$ fueron $-442(-390)$ y $-460(-417) \mathrm{Wm}^{-2}$, respectivamente. La $\mathrm{CRE}_{0}$ muestra una relación lineal con $\ln (\mathrm{COD})$, siendo más fuerte a medida que disminuye el ángulo cenital solar. La eficiencia del efecto de las nubes (CEE) para $\mathrm{Cu}$ y Sc-Cu disminuye bruscamente con el aumento del valor de COD hasta 20, disminuyendo lentamente para valores mayores de COD.
\end{abstract}

\begin{abstract}
The effects of cumulus $(\mathrm{Cu})$ clouds and the combination of stratocumulus-cumulus $(\mathrm{Sc}-\mathrm{Cu})$ clouds on solar radiation at the Earth's surface were evaluated at Camagüey, Cuba, during a 6-yr period (from June 2010 to May 2016). Two methods to calculate the cloud radiative effect (CRE) were employed. The first method $\left(\mathrm{CRE}_{\mathrm{m}}\right)$ uses solar irradiances in cloudy conditions from actinometric observations, where cloud information was also reported by visual observation. In the second method $\left(\mathrm{CRE}_{0}\right)$ surface solar irradiances were estimated for both cloudy and clear sky conditions using a 1-D radiative transfer model, and cloud optical depth (COD) retrieved from an AERONET sun-photometer as the main input. A temporal correspondence criterion between COD retrievals and actinometric observations was performed in order to classify the COD of each cloud type. After the application of this criterion, the COD belonging to the optically thin clouds was removed. Finally, 255 and $732 \mathrm{COD}$ observations for $\mathrm{Cu}$ and $\mathrm{Sc}-\mathrm{Cu}$, respectively, were found. Results show
\end{abstract}


a statistically significant difference at the $95 \%$ confidence level between $\mathrm{CRE}$ calculated for $\mathrm{Sc}-\mathrm{Cu}$ and $\mathrm{Cu}$, using both methods. Mean values of $\mathrm{CRE}_{\mathrm{m}}$ and $\mathrm{CRE}_{0}$ for $\mathrm{Cu}(\mathrm{Sc}-\mathrm{Cu})$ were $-442(-390)$ and $-460(-417)$ $\mathrm{Wm}^{-2}$, respectively. $\mathrm{CRE}_{0}$ shows a linear relation with $\ln (\mathrm{COD})$, with stronger correlation at a lower solar zenith angle. The shortwave cloud effect efficiency (CEE) for the two cloud types sharply decreases with the increase of the COD value up to 20. For larger COD, the CEE is less sensitive to the increase of COD.

Keywords: cloud effects on solar radiation (CRE) at surface, cloud optical depth (COD), cumulus and stratocumulus, cloud effect efficiency (CEE).

\section{Introduction}

Clouds are an important component of climate due to their complex interactions with other components of the climatic system. The main interaction is thwir influence on the radiative transfer in solar or shortwave radiation (spectral interval: 0.2 to $4 \mu \mathrm{m}$ ) and in terrestrial or longwave radiation (spectral interval higher than $4 \mu \mathrm{m}$ ). Those interactions occur via the scattering and absorption within the solar spectrum, and mainly by absorption and emission within the terrestrial spectrum. The main effect of clouds on solar radiation is the large backward scattering produced by cloud droplets and ice crystals (Liou, 1986; Stephens, 2005; Mitchell and Finnegan, 2009). As a result, the earth-atmosphere system albedo basically depends on clouds and their properties.

At the Earth's surface, the clouds effect on solar radiation basically depends on the microphysical (i.e., particle size) and macrophysical (i.e., cloud base and cloud top) properties of clouds and the sun disk location with respect to the measuring point. For instance, when a cloud completely or partially obstructs the sun disk, the result is a reduction of downward irradiance at the Earth's surface, producing a radiative cooling effect. In addition, in partially cloud-covered situations, such as low broken cloud fields, the surface irradiance can exceed the expected clear sky irradiance value, causing radiative heating at surface. This phenomenon is known as cloud enhancement effect and can be observed all around the world (Gueymard, 2017). The enhancement is produced under a clear sun disk by the increase of diffuse shortwave irradiance due to the presence of clouds. To detect this effect, it is necessary to perform continuous solar radiation measurements and to estimate the expected instantaneous cloudless radiation. Hereinafter the terms cooling or heating will refer to the radiative cooling or heating.
One of the first results reported in scientific literature about the clouds effect on solar radiation was reported in the 1940s (Neiburger, 1949). The author computed the cloud radiative properties using downward and upward shortwave radiation measurements below, inside and above the coastal stratus clouds in the USA. In the 1980s there was an increase in studies estimating the cloud radiative properties (reflectivity, absorptivity and transmissivity), and their relationship with macr physical, microphysical and optical properties of the clouds (e.g., Ackerman and Stephens, 1987). After the creation of the International Satellite Cloud Climatology Project (ISCCP) (Schiffer and Rossow, 1983) these studies were substantially increased. This project enabled an improvement in the estimation of the cloud radiative effects and cloud optical depth (COD) (Chou and Zhao, 1997; Chen et al., 2000).

More recent polar orbit satellite-based projects have helped to improve in depth these studies, such as the A-Train constellation, which comprises the Cloud Aerosol Lidar and Infrared Pathfinder Satellite Observation (CALIPSO) (Winker et al., 2007), Cloud Sattleite (CloudSat) (Stephens et al., 2008), MODerate-resolution Imaging Spectroradiometer (MODIS) (Barnes et al., 1998) and the Clouds and the Earth's Radiant Energy System (CERES) (Wielicki et al., 1996) instruments onboard Aqua and Terra satellites. These instruments allow for analyzing the cloud radiative effects considering the vertical structure of the clouds (L'Ecuyer et al., 2008; Li et al., 2011; Ham et al., 2017; Dolinar et al., 2019).

In the Caribbean region, there have been few studies about this topic. This is specifically the case of Cuba, despite its tropical location and the high frequency of low clouds. Martínez and Pomares (2002) evaluated the effect of cloud cover on the UV radiation transmittance, without specifying the cloud type. The pioneering study in Cuba about the effect 
of cirrus clouds on solar radiation was carried out by Barja and Antuña-Marrero (2008, 2010, 2011), estimating the microphysical properties of cirrus clouds and their shortwave radiative effect. The authors reported a daily mean value of shortwave cloud radiative effect (SWCRE, formerly shortwave cloud radiative forcing, hereinafter $\mathrm{CRE}$ ) of $-5.6 \mathrm{Wm}^{-2}$ and a cloud effect efficiency (formerly cloud radiative efficiency, hereinafter CEE) of $-26 \mathrm{Wm}^{-2} \mathrm{COD}^{-1}$, both at the surface. Cirrus cloud properties have also been described for Cuba and the Wider Caribbean (Barja and Antuña-Marrero, 2010; Barja et al., 2012).

Despite the important role of clouds in the Earth's radiation budget, the number of experimental sites conducting measurements of cloud properties is not yet enough to produce detailed information on the different regions of the Earth. For that reason, the cloud radiative effect at surface has been less reported by the scientific community than cloud effects at the top of atmosphere (Boucher et al., 2013). This whole scenario demonstrates the importance of studies about clouds and their interaction with solar radiation at the Earth's surface.

Therefore, this paper presents an estimation of the effect of cumulus $(\mathrm{Cu})$ and stratocumulus-cumulus ( $\mathrm{Sc}-\mathrm{Cu})$ cloud types on the solar irradiance at the surface at Camagüey, Cuba $\left(21.42^{\circ} \mathrm{N}, 77.85^{\circ} \mathrm{W}\right.$, 122 masl), $2 \mathrm{~h}$ before and after 12:00 LT. Sun-photometric and actinometric measurements at the site were used in conjunction with a 1-D atmospheric radiative transfer model (RTM) and satellite-derived products. A brief description of the instruments, datasets and RTM calculations is shown in section 2. Section 3 shows the results and the discussion. Finally, section 4 concludes and summarizes this study.

\section{Data and methods}

2.1 COD, actinometric datasets, and correspondence criterion

Our study period spans six years from June 2010 to May 2016, at the Meteorological Station of Camagüey, Cuba. At this site, in addition to the meteorological devices, an actinometric station and the AERONET Cimel sun-photometer were installed as close as tens of meters.

The Cimel CE 318 sun-photometer was installed at the Camagüey Meteorological Station $\left(21.42^{\circ} \mathrm{N}\right.$, $77.85^{\circ} \mathrm{W}, 122 \mathrm{masl}$ ) as part of AERONET (AErosol RObotic NETwork) (Holben et al., 1998) in 2006, due to a research collaboration agreement between the Cuban Meteorological Institute at Camagüey and the University of Valladolid (Spain). It has nine interference filters centered at 340, 380, 440, 500, 675, $870,935,1020$, and $1640 \mathrm{~nm}$ nominal wavelengths. The main objective of this instrument is to retrieve the spectral aerosol optical depth (AOD) from direct solar irradiance at the surface. When the clouds block the sun disk, it is not possible to retrieve the AOD. Under such conditions, the instrument carries out 10 radiance measurements towards the zenith for all spectral channels, in the so-called "cloud mode". Using these zenith radiance measurements at 440 and $870 \mathrm{~nm}$ as inputs into lookup-tables created using a radiative transfer algorithm (Chiu et al., 2010), the COD parameter can be retrieved. For the study period, a total of 8997 COD observations were carried out with the AERONET cloud mode level 2.

Barja et al. (2012) developed a 1-yr preliminary study in order to evaluate the AERONET COD measurements at the Camagüey site. An algorithm was used to determine the "correct" COD values. The term correct must be understood in two senses: first, there was a cloud present in the sky and therefore the decision to make a COD measurement with the sun-photometer was correct; second, this COD value is related to cloud type and cloud cover information recorded in the actinometric report (more details of the algorithm are provided in Barja et al., 2012). The authors showed that a high percentage of COD data from AERONET was correct and in very good agreement with CALIPSO data for COD values lower than 5 .

In the actinometric station of the site, visual observations of clouds and manual irradiance measurements were conducted 12 min after each hour during daytime. A Yanishevsky pyranometer (M-80-M or M-115-M) connected to an analogic galvanometer (GSA-1MA or GSA-1MB) along with a shadow cover, were manually operated to measure broadband global, diffuse, and direct components of solar irradiance at the surface.

Before, during and after measurements in the actinometric station, the observer reported some characteristics of the weather and surface (e.g., air temperature, wind speed, color of the sky, cloud 
types, cloud cover, temperature of the soil surface, visibility range, and state of the sun disk). Cloud types observed in the sky, including those at the zenith, were reported by the observer, following the classification of clouds given by the World Meteorological Organization (WMO, 2017).

The state of the sun disk is classified in four categories: (1) sun disk not covered by clouds: no traces of clouds, mist, haze or dust on the disk of the sun and within a radius of $5^{\circ}$; (2) sun disk partially covered by thin clouds: the sun shines through clouds, fog or smoke and the actinometer tube can collimate the sun; (3) sun disk totally covered by thick clouds: the sun disk is weakly visible through a layer of dense clouds, and it is impossible to aim the actinometer tube at the sun, and (4) sun disk totally covered by dense clouds: the sun is not visible through dense clouds (Yanishevsky 1957; Ross et al., 1969; Antuña-Marrero et al., 2008; Eerme and Aun, 2012; Chervyakov and Neishtadt, 2018).

Manually operated solar radiation stations are becoming practically extinct, replaced by automatic instruments. But in Cuba these manual stations are still functional and the plan is to continue operating them during the next years. Therefore, data provided by these instruments are useful to obtain and study atmospheric parameters such as clouds. The dataset was subjected to an improved quality control and processing algorithm (Antuña-Marrero et al., 2008, 2018, 2019). In the present work we used shortwave global downward irradiance $(G)$, shortwave upward irradiance $(R)$, cloud type and low cloud amount from actinometric measurements.

Measurements with the actinometric station made when the sun disk is partially and completely covered by thin and thick clouds (sun disk 2-4) were employed for this study. In addition, in order to find COD and irradiance measurements in the presence of the cloud types of interest, a correspondence criterion was applied. The combination of COD measurements and the visual reports of clouds from the actinometric observations is the aim of this correspondence criterion, whose conditions are:

1. Select visual reports with only $\mathrm{Sc}-\mathrm{Cu}$ or $\mathrm{Cu}$ cloud types.

2. Time range is set between $15: 00$ and 19:00 UTC (from 10:00 to 14:00 LT). In this time interval the solar zenith angle is smaller, therefore it increase the probability that the sun-photometer measures the same clouds as the actinometric instrument.

3. The coincident COD measurements with $\mathrm{Sc}-\mathrm{Cu}$ or $\mathrm{Cu}$ visual reports are selected in the time interval of $2 \mathrm{~min}$ before and $30 \mathrm{~min}$ after the start time of the actinometric observation (it must be noted that actinometric measurements last about $30 \mathrm{~min}$ and the report of the cloud is done $2 \mathrm{~min}$ before the radiation measurement, which is why this asymmetrical time interval is chosen).

When the first condition of the criterion was applied, a total of 1447 and 852 cases of actinometric reports in presence of $\mathrm{Sc}-\mathrm{Cu}$ and $\mathrm{Cu}$ were found, respectively. Finally, after the application of all conditions of the correspondence criterion, a total of 876 and 314 actinometric measurements were coincident with COD retrievals corresponding to $\mathrm{Sc}-\mathrm{Cu}$ and $\mathrm{Cu}$, respectively.

\subsection{Atmospheric Radiative Transfer model, CRE and CEE computations}

A 1-D radiative transfer of the National Oceanic and Atmospheric Administration (NOAA) is used to calculate the solar radiation fluxes at the surface (Freidenreich and Ramaswamy, 1999, 2005). The RTM solves the atmospheric radiative transfer equation using the delta Eddington and double adding method and only considers the term related to atmospheric extinction in the solar (or shortwave) spectrum.

The model has a high vertical resolution with the atmosphere divided in 122 layers and pressure levels ranging from 3.10 to $1013.25 \mathrm{hPa}$. It also includes gas absorption (water vapor, $\mathrm{CO}_{2}, \mathrm{O}_{2}$, and $\mathrm{O}_{3}$ ), Rayleigh scattering, scattering and absorption of aerosols, water droplets and ice particles. The model assumes clouds as a homogeneous and in a parallel plane layer (conditions similar to overcast sky), with the parameterization scheme for water clouds provided by Slingo (1989).

This RTM was adapted to the Camagüey meteorological conditions and has demonstrated a good agreement with experimental solar radiation measurements for clear sky and cloudy conditions (Barja and Antuña-Marrero, 2011; Freidenreich and Ramaswamy, 2011). Water vapor mixing ratio vertical profiles were collected using a radiosounding 
dataset carried out at Camagüey from 1991 to 1988. A surface albedo average value of 0.22 , obtained from actinometric measurements at the site, was used in the calculations. The vertical profile of ozone mass mixing ratio was taken from the mid-latitude summer (MLS) atmosphere of McClatchey et al. (1972).

The effect of low clouds on solar radiation was estimated by calculating the shortwave cloud radiative effect at the surface (CRE). Two methods were used to calculate CRE: in the first one, actinometric measurements for cloudy conditions and modeling of the clear sky to generate $\mathrm{CRE}_{\mathrm{m}}$ were used (Eq. [1]); the second one was carried out using only the modeling of both clear and cloudy conditions to obtain $\mathrm{CRE}_{0}$ (Eq. [2]).

$\mathrm{CRE}_{\mathrm{m}}$ was calculated through the difference between measured net solar surface irradiance in cloud presence $\left(I_{\text {cloud }}\right.$ meas $)$ and the modeled one in clear sky conditions at the same time $\left(I_{\text {clear }}^{0}\right)$. Net solar irradiance on the surface in the presence of clouds was estimated by with Eq. (3) ( $G$ and $R$ were defined above).

$C R E_{m}=I_{\text {cloud }}^{\text {meas }}-I_{\text {clear }}^{0}$

$I_{\text {cloud }}^{\text {meas }}=G-R$

$C R E_{o}=I_{\text {cloud }}^{0}-I_{\text {clear }}^{0}$

From the theoretical evaluation of $I_{\text {clear }}^{0}$, the most important component is aerosol, hence AOD values were estimated as a temporal interpolation of the daily mean AOD (500 nm) obtained by the AERONET sun-photometer. Vertical distribution of aerosol in the RTM was assumed in a layer between ground and $3 \mathrm{~km}$.

The main inputs in cloudy conditions to obtain $C R E_{0}$ were COD, the effective radius of the cloud droplet distribution $\left(r_{e}\right)$ and cloud geometrical properties. Because no measurements of geometrical cloud properties and $r_{e}$ are available at our site, cloud properties used in the model were taken from literature and MODIS data (see Table I). Cloud base $\left(Z_{\mathrm{b}}\right)$ and top $\left(Z_{\mathrm{t}}\right)$ height for each cloud type were included in their respective pressure levels by the interpolation with the tropical atmosphere profile from McClatchey et al. (1972). Note that $Z_{\mathrm{b}}$ and $Z_{\mathrm{t}}$ have the same values for both $\mathrm{Sc}-\mathrm{Cu}$ and $\mathrm{Cu}$.

Table I. Cloud properties assumed in this study.

\begin{tabular}{lccc} 
Cloud type & $\begin{array}{c}Z_{\mathrm{b}} \\
(\mathrm{km})\end{array}$ & $\begin{array}{c}Z_{\mathrm{t}} \\
(\mathrm{km})\end{array}$ & $\begin{array}{c}r_{\mathrm{e}} \\
(\mu \mathrm{m})\end{array}$ \\
$\mathrm{Cu}$ & 1.7 & 2.15 & 12 \\
$\mathrm{Sc}-\mathrm{Cu}$ & 1.7 & 2.15 & 15 \\
\hline
\end{tabular}

$Z_{\mathrm{b}}$ : cloud base; $Z_{\mathrm{t}}$ : cloud top; $r_{\mathrm{e}}$ : cloud droplet distribution; $\mathrm{Cu}$ : cumulus; Sc-CU: stratocumulus-cumulus.

The selection of the mean $r_{e}$ was based on literature (e.g., Zhang et al., 1995; Kim et al., 2003; Allan et al., 2008; Spiegel et al., 2014) and from climatological data obtained from the Goddard Earth Sciences Data and Information Services Center (GES DISC) Interactive Online Visualization and Analysis Infrastructure (Giovanni). MODIS provides a mean value for $r_{e}$ of $15.6 \mu \mathrm{m}$ within the range from 8 to 26 $\mu \mathrm{m}$, without any identification relative to cloud type, based on daily average values for the period 2000 to 2014. To assume a fixed value for the effective radius $r_{e}$ may appear non-realistic, but we must note that $r_{e}$ is far less sensitive to shortwave surface transmitted radiation as has been demonstrated in various studies (e.g., McBride et al., 2011). Chiu et al. (2010) retrieved COD assuming a fixed value of $8 \mu \mathrm{m}$, but a $25 \%$ error in this parameter only implies a $4 \%$ error in the COD. Therefore, we used a fixed $r_{e}$ for each cloud type (see Table I) as the most adequate value for the modeling of radiative fluxes in the presence of clouds.

We computed the CRE using the net flux (Eq. [3]), similar to other studies (e.g., Berg et al., 2011), rather than using only the downward flux (e.g., McFarlane et al., 2012). Therefore, care must be taken when comparisons are made. The main errors in the estimation of CRE are associated with instrumental errors and errors in the modeling of radiative fluxes, because of the assumption of 1-D RTM for non-overcast conditions. Due to the ageing of the actinometric instruments, the magnitude of error associated with the broadband pyranometer is estimated to be about 10\% (Antuña-Marrero et al., 2008). The error of radiative flux calculations with the RTM is $10 \%$ for 
clear sky (Freidenreich and Ramaswamy, 2011) and between 20 and 30\% in cloudy conditions ( $\mathrm{Li}$ and Trishchenko, 2001).

Considering all the above-mentioned errors, the total uncertainty of the methods used to determine CRE and CEE is between 20 and 40\%. In the case of overcast sky, the error can be higher, between 30 and $40 \%$ (20 to 30\% related with model calculations plus $10 \%$ of the observations); and $20 \%$ for clear sky (10\% related with the model calculations plus $10 \%$ of the observations).

The number of $\mathrm{CRE}_{\mathrm{m}}$ cases was higher than $\mathrm{CRE}_{0}$ because of the lower number of coincident actinometric measurements in presence of clouds with available COD data. As expected, CRE exhibits negative values, showing a reduction of solar radiation at the surface by the presence of clouds. High absolute values of CRE correspond to a higher decrease of the solar radiation. Hence, hereinafter we will not consider the sign in the CRE when we talk about higher or lower values.

CRE provides the actual radiative effect of clouds, but in order to make a consistent comparison between different clouds (clouds with different microphysical and macrophysical properties) the shortwave cloud effect efficiency (CEE), also known in the literature as cloud forcing efficiency (Mateos et al., 2014) is a more appropriate magnitude defined as the rate at which the cloud radiative effect is forced per unit of COD. CEE is then calculated in order to evaluate the change in the cloud effect per unit of COD, and can be obtained as the following relation, using small intervals of SZA (Mateos et al., 2014):

$$
C E E=\frac{m}{C O D}
$$

where $m$ is the slope of the linear fit between CRE and $\ln (\mathrm{COD})$ (in $\mathrm{Wm}^{-2}$ ) for each SZA interval. Therefore, the units of CEE are $\mathrm{Wm}^{-2}$ per COD unit, presenting dependence on both SZA and COD. The physical meaning of $m$ is related to absolute changes in CRE due to relative changes on COD. However, in order to evaluate cloud efficiency in terms of radiative effects with the absolute change of COD, we need to check this change in COD units, which is not directly retrieved from the slope. CEE is a useful parameter to compare different cloud types with the same COD, because the influence of other factors such as absorbing and scattering cloud properties may become more evident. Nonetheless, when analyzing the efficiency values, it is necessary to be careful with high CODs (Mateos et al., 2014), since for these values a high concentration of cloud droplets is expected and hence the saturation of CEE due the increase in multiple scattering. In this study, CEE was only calculated for $\mathrm{CRE}_{0}$ values because enough COD data are only available for these cases.

\subsection{Cleaning of the data set to remove doubtful measurement cases}

Preliminary analyses of the frequency distribution of $\mathrm{CRE}$ for $\mathrm{Cu}$ and $\mathrm{Sc}-\mathrm{Cu}$ near noon, calculated with the two methods, are shown in Figure 1. For Cu (Fig. 1a) 852 and 314 cases of $\mathrm{CRE}_{\mathrm{m}}$ and $\mathrm{CRE}_{0}$, respectively, were found. There were 1447 and 876 cases of $\mathrm{CRE}_{\mathrm{m}}$ and $\mathrm{CRE}_{0}$ for $\mathrm{Sc}-\mathrm{Cu}$ (Fig. 1b). The cases that satisfied the first condition of the correspondence criterion were used to calculate CREm. The cases that successfully met all conditions of the correspondence criterion were used to calculate $\mathrm{CRE}_{0}$. Figure 1a shows differences between both CRE histograms for $\mathrm{Cu}$. The highest frequency value $(27 \%)$ of $\mathrm{CRE}_{0}$ is placed in the range from 0 to $-100 \mathrm{Wm}^{-2}$. However, the highest frequency value $(36 \%)$ for $\mathrm{CRE}_{\mathrm{m}}$ is in the interval from -400 to $-500 \mathrm{Wm}^{-2}$, with no frequency values in the range from 0 to $-100 \mathrm{Wm}^{-2}$. Figure 1 b shows CRE histograms for $\mathrm{Sc}-\mathrm{Cu}$. As with $\mathrm{Cu}$, there are no values for $\mathrm{CRE}_{\mathrm{m}}$ in the interval from 0 to $-100 \mathrm{Wm}^{-2}$. The maximum frequencies for both $\mathrm{CRE}_{\mathrm{m}}$ and $\mathrm{CRE}_{0}$ are observed in the interval from -300 to $-400 \mathrm{Wm}^{-2}$, with 36 and $27 \%$, respectively.

T-Student tests were applied to check the differences between $\mathrm{CRE}_{\mathrm{m}}$ and $\mathrm{CRE}_{0}$, showing statistically significant differences at the $95 \%$ confidence level for $\mathrm{Cu}$ and $\mathrm{Sc}-\mathrm{Cu}$. This is largely due to the differences observed in the range of 0 to $-100 \mathrm{Wm}^{-2}$, which could be due to the fact that COD values employed in the modeling were not related to the same cloud types measured with the actinometric technique.

When zenith sky radiance is measured in cloud mode with the sun-photometer and there are interstices between clouds, the instrument can measure a different cloud type than the one reported by the observer. Low COD values causing CRE values below $-100 \mathrm{Wm}^{-2}$ are considered doubtful because they do not correspond to low water clouds near 

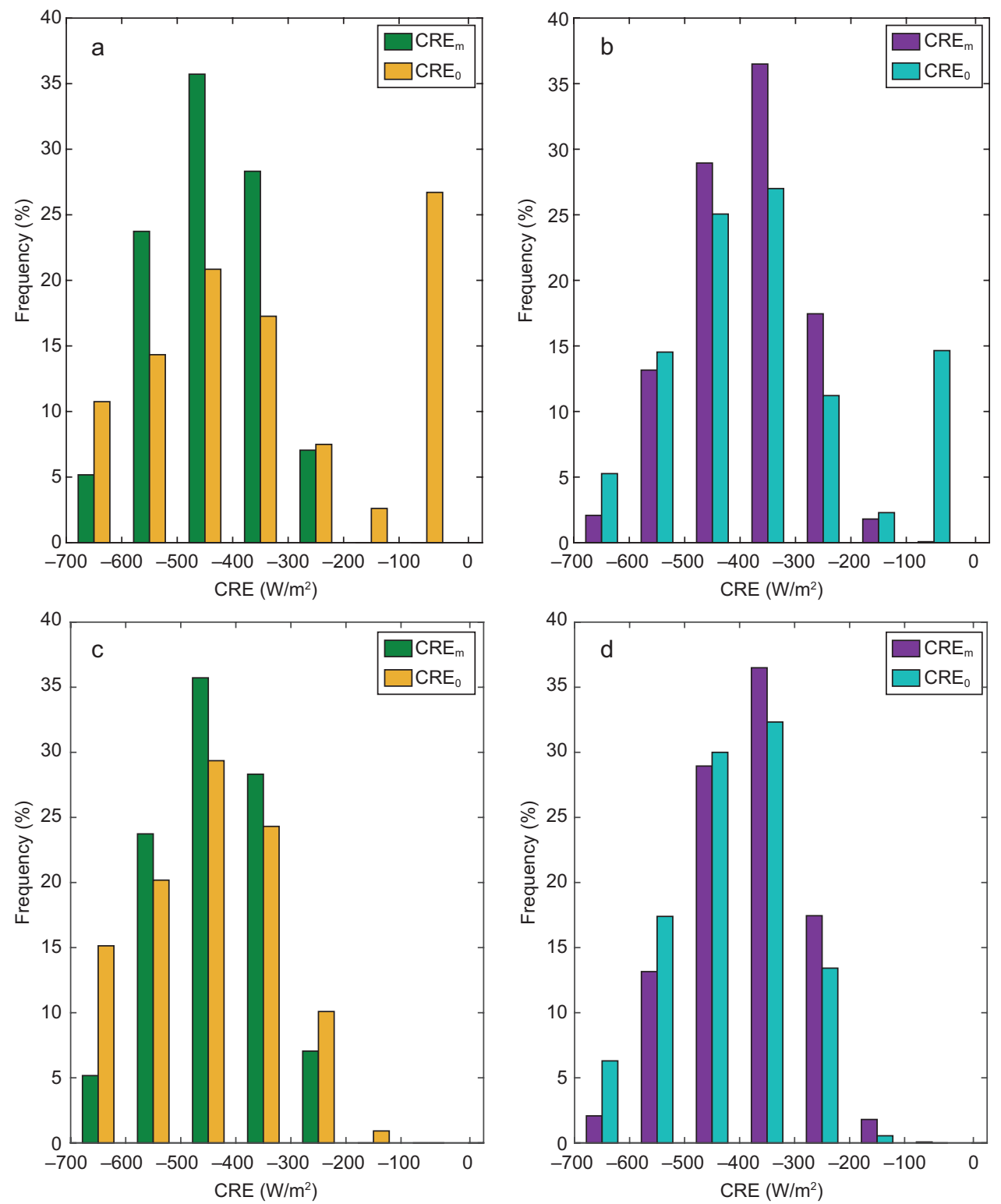

Fig. 1. Frequency distributions of $\mathrm{CRE}_{\mathrm{m}}$ and $\mathrm{CRE}_{0}$ for (a) $\mathrm{Cu}$ and (b) $\mathrm{Sc}-\mathrm{Cu}$ cloud types. (c) and (d) as in (a) and (b) after discarding doubtful COD values. (CRE: cloud radiative effect at the surface; $\mathrm{CRE}_{\mathrm{m}}$ : $\mathrm{CRE}$ from actinometric measurements; $\mathrm{CRE}_{0}$ : modeled CRE; $\mathrm{Cu}$ : cumulus; Sc-CU: stratocumulus-cumulus).

noon. The term doubtful is used, hereinafter, for these COD measurements with low values producing high differences with CRE values determined with both methods. The Sc-Cu morphology is closer to cloud representation in the radiative transfer code (plane-parallel) than $\mathrm{Cu}$. In addition, this cloud combination has great horizontal extension, which leads to lesser occurrence of interstices and therefore lower occurrence of small COD values when CODs from sun-photometric measurement are compared to actinometric measurements reports.

In order to clean the dataset to reduce the amount of doubtful COD values, it is necessary to check the consistency between the values of CRE methods and the reported cloud type. Differences between $\mathrm{CRE}_{\mathrm{m}}$ and $\mathrm{CRE}_{0}$ for each cloud type, as a function of COD, 
were calculated for cases with stricter coincident criterion (Fig. 2). This criterion was set between 12 and $20 \mathrm{~min}$ in each measurement hour. After applying this criterion, 79 and 280 cases of COD were found for $\mathrm{Cu}$ and $\mathrm{Sc}-\mathrm{Cu}$, respectively.

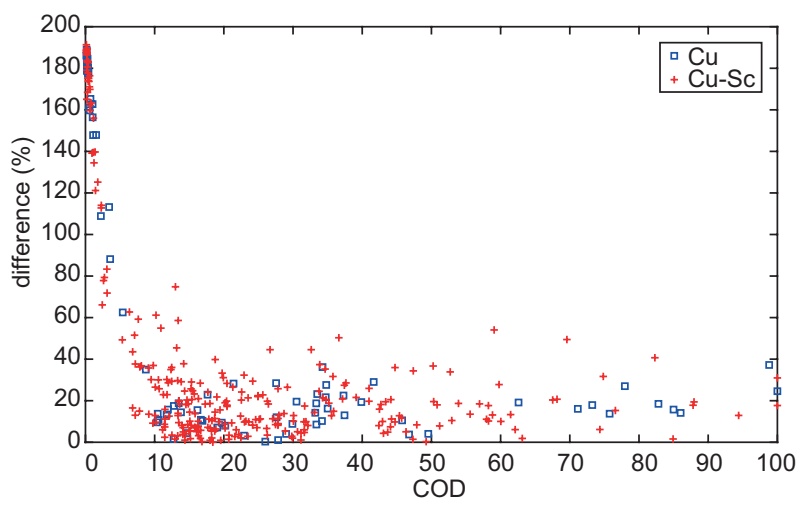

Fig. 2. Percentage differences between $C R E_{m}$ and $C R E_{0}$ for coincident cases in relation with COD for the two cloud types, $\mathrm{Cu}$ and $\mathrm{Cu}-\mathrm{Sc}$. (CRE: cloud radiative effect at the surface; $\mathrm{CRE}_{\mathrm{m}}$ : $\mathrm{CRE}$ from actinometric measurements; $\mathrm{CRE}_{0}$ : modeled CRE; $\mathrm{Cu}$ : cumulus; $\mathrm{Sc}-\mathrm{CU}$ : stratocumulus-cumulus; COD: cloud optical depth).

In Figure 2, higher differences $(>150 \%)$ in the small-COD values region (which corresponds to the range of doubtful COD values) were found.
Therefore, it is evident that these COD values are not related with the reported cloud type. These COD values are characteristic of optically thin clouds, such as subvisible cirrus clouds or low minor clouds that cannot be sufficiently measured by the actinometric method. Hence, a threshold COD value for each cloud type was determined by a minimum COD value of the subset of COD with differences below $60 \%$. The selection of this difference value was based on the fact that $70 \%$ of the studied cases are below it. For both cloud types, the threshold COD was found to be 5 , thus any lower COD was removed from the analysis.

The number of cases resulting from the correspondence criterion which remain after the removal of doubtful COD values were 225 and 732 for $\mathrm{Cu}$ and $\mathrm{Sc}-\mathrm{Cu}$, respectively. The cleaned dataset was used for further analysis and results.

Figure 3 shows the frequency distributions of $\mathrm{COD}$ for $\mathrm{Cu}$ and $\mathrm{Sc}-\mathrm{Cu}$ after the removal of doubtful COD cases. The COD frequency distribution for $\mathrm{Cu}$ (Fig. 3a) has its $15 \%$ peaks in the COD interval with central values of 10 and 15 , with $80 \%$ of the distribution below 45. In the case of $\mathrm{Sc}-\mathrm{Cu}$ (Fig. 3b), the COD frequency distribution has its maximum frequency $(18 \%)$ in the COD interval with central values of 10 and 15 , similar to $\mathrm{Cu}$, with $85 \%$ of the distribution below 45. The mean values of COD for $\mathrm{Sc}-\mathrm{Cu}$ and $\mathrm{Cu}$ were 29.6 and 34.2, respectively. As

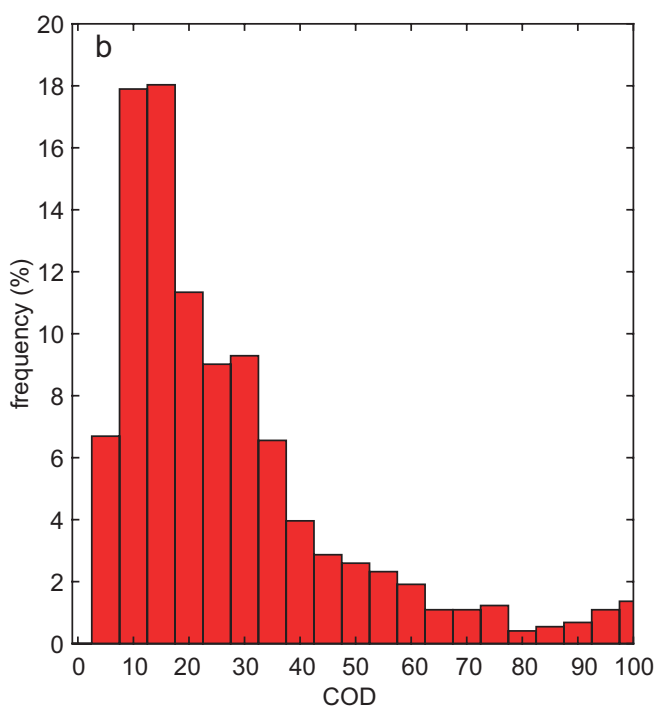

Fig. 3. Frequency distributions of COD for (a) $\mathrm{Cu}$ and (b) $\mathrm{Sc}-\mathrm{Cu}$. (COD: cloud optical depth; $\mathrm{Cu}$ : cumulus; Sc-CU: stratocumulus-cumulus). 
observed above, the COD frequency distributions for both cloud types are similar, but the Sc-Cu maximum is higher than the $\mathrm{Cu}$ maximum, and the distribution of $\mathrm{Cu}$ has a secondary maximum of $4 \%$ in the COD interval of 65 .

\section{Results and discussion}

\subsection{Frequency and statistical values of CRE}

The CRE frequency distribution for $\mathrm{Cu}$ and Sc$\mathrm{Cu}$ after discarding doubtful values is shown in Figure 1c, d, where a decrease in the frequency within doubtful intervals of $\mathrm{CRE}_{0}$ is observed. There is not data in the interval from 0 to $-100 \mathrm{Wm}^{-2}$, where the maximum frequency was previously located for both cloud types. Only a low value of $1 \%$ for $\mathrm{CRE}_{0}$ in the frequency interval from -100 to $-200 \mathrm{Wm}^{-2}$ was observed for both cloud types. The maximum frequencies of $\mathrm{CRE}_{0}$ after discarding doubtful COD values are observed in the intervals from -400 to -500 and -300 to $-400 \mathrm{Wm}^{-2}$ for $\mathrm{Cu}$ and $\mathrm{Sc}-\mathrm{Cu}$, respectively. Similar behavior was found regarding the $\mathrm{CRE}_{\mathrm{m}}$ frequency distribution.

Hypothesis t-Student tests for $\mathrm{Cu}$ and $\mathrm{Sc}-\mathrm{Cu}$ were applied showing no statistically significant differences between $\mathrm{CRE}_{\mathrm{m}}$ and $\mathrm{CRE}_{0}$ at the $95 \%$ confidence level. However, the existing differences between $\mathrm{CRE}_{\mathrm{m}}$ and $\mathrm{CRE}_{0}$ for a given cloud type are due to different causes, e.g., the uncertainties related to the input parameters for the modeled data and the assumption of 1-D RTM for non-overcast conditions, which can overestimate the surface irradiances for cloudy conditions. In addition, temporal differences in measurement methodologies between the actinometric and sun-photometer measurements can also be an important factor.

Table II shows statistics (mean, standard deviation [std], maximum [max], minimum [min], and percentiles 5, 95 and 50 [median]) of $\mathrm{CRE}_{\mathrm{m}}$ and $\mathrm{CRE}_{0}$ for each cloud type after discarding doubtful COD values. We consider the absolute value when referring to CRE maximum or minimum. As shown in Table II, $\mathrm{Cu}$ clouds have smaller differences between $\mathrm{CRE}_{\mathrm{m}}$ and $\mathrm{CRE}_{0}$ than $\mathrm{Sc}-\mathrm{Cu}$. For $\mathrm{Cu}$, the mean values of CRE are -442 and $-460 \mathrm{Wm}^{-2}$ for $\mathrm{CRE}_{\mathrm{m}}$ and $\mathrm{CRE}_{0}$, respectively. In the case of $\mathrm{Sc}-\mathrm{Cu}$, $\mathrm{CRE}$ is lower than $\mathrm{Cu}$, with mean values of -390 and $-417 \mathrm{Wm}^{-2}$ for $\mathrm{CRE}_{\mathrm{m}}$ and $\mathrm{CRE}_{0}$, respectively. There is a slightly higher dispersion of $\mathrm{CRE}_{0}$ than $\mathrm{CRE}_{\mathrm{m}}$ values because of the possible existence of non-discarded doubtful COD values. We found statistically significant differences at the $95 \%$ confidence level between $\mathrm{Cu}$ and $\mathrm{Sc}-\mathrm{Cu}$ for both $\mathrm{CRE}_{\mathrm{m}}$ and $\mathrm{CRE}_{0}$. Percentiles 95 and 5 show higher values for the $\mathrm{Cu}$ cloud type. $\mathrm{CRE}_{\mathrm{m}}$ values of percentiles 95 (5) for $\mathrm{Cu}$ and $\mathrm{Sc}-\mathrm{Cu}$ were $-603(-292)$ and $-567(-230) \mathrm{Wm}^{-2}$, respectively. Therefore, we can conclude that $\mathrm{Sc}-\mathrm{Cu}$ clouds produce a lower effect on solar radiation than $\mathrm{Cu}$ clouds.

\subsection{Relationship between CRE and the cosine of so- lar zenith angle (CSZA)}

The dependence of solar irradiance to the sun position is transmitted to CRE values, and this behavior is analyzed here in relation to the cosine of solar zenith angle (CSZA). In Figure 4, $\mathrm{CRE}_{\mathrm{m}}$ and $\mathrm{CRE}_{0}$ versus CSZA for both studied cloud types are shown. Note that for $\mathrm{Cu}$ (Fig. 4a), $\mathrm{CRE}_{\mathrm{m}}$ and $\mathrm{CRE}_{0}$ decrease

Table II. Statistical values of $\mathrm{CRE}_{\mathrm{m}}$ and $\mathrm{CRE}_{0}$ for each cloud type. CRE maxima and minima are determined with the modulus or absolute value.

\begin{tabular}{|c|c|c|c|c|c|c|c|c|}
\hline \multirow{2}{*}{ Cloud type } & \multirow{2}{*}{$\mathrm{e}_{\left(\mathrm{Wm}^{-2}\right)}^{\mathrm{CRE}}$} & \multirow{2}{*}{ Mean } & \multirow{2}{*}{$\begin{array}{l}\text { Standard } \\
\text { deviation }\end{array}$} & \multicolumn{3}{|c|}{ Percentiles } & \multirow{2}{*}{ Maximum } & \multirow{2}{*}{ Minimum } \\
\hline & & & & 5 th & 50 th & 95th & & \\
\hline $\mathrm{Cu}$ & $\begin{array}{l}\mathrm{CRE}_{\mathrm{m}} \\
\mathrm{CRE}_{0}\end{array}$ & $\begin{array}{l}-442 \\
-460\end{array}$ & $\begin{array}{r}95 \\
131\end{array}$ & $\begin{array}{l}-292 \\
-250\end{array}$ & $\begin{array}{l}-442 \\
-448\end{array}$ & $\begin{array}{l}-603 \\
-682\end{array}$ & $\begin{array}{l}-700 \\
-722\end{array}$ & $\begin{array}{l}-208 \\
-180\end{array}$ \\
\hline $\mathrm{Sc}-\mathrm{Cu}$ & $\begin{array}{l}\mathrm{CRE}_{\mathrm{m}} \\
\mathrm{CRE}_{0}\end{array}$ & $\begin{array}{l}-390 \\
-417 \\
\end{array}$ & $\begin{array}{l}102 \\
111 \\
\end{array}$ & $\begin{array}{l}-230 \\
-251 \\
\end{array}$ & $\begin{array}{l}-384 \\
-417 \\
\end{array}$ & $\begin{array}{l}-567 \\
-619 \\
\end{array}$ & $\begin{array}{l}-722 \\
-728 \\
\end{array}$ & $\begin{array}{r}-99 \\
-121 \\
\end{array}$ \\
\hline
\end{tabular}

CRE: cloud radiative effect at the surface; CREm: CRE from actinometric measurements; CRE0: modeled CRE. 

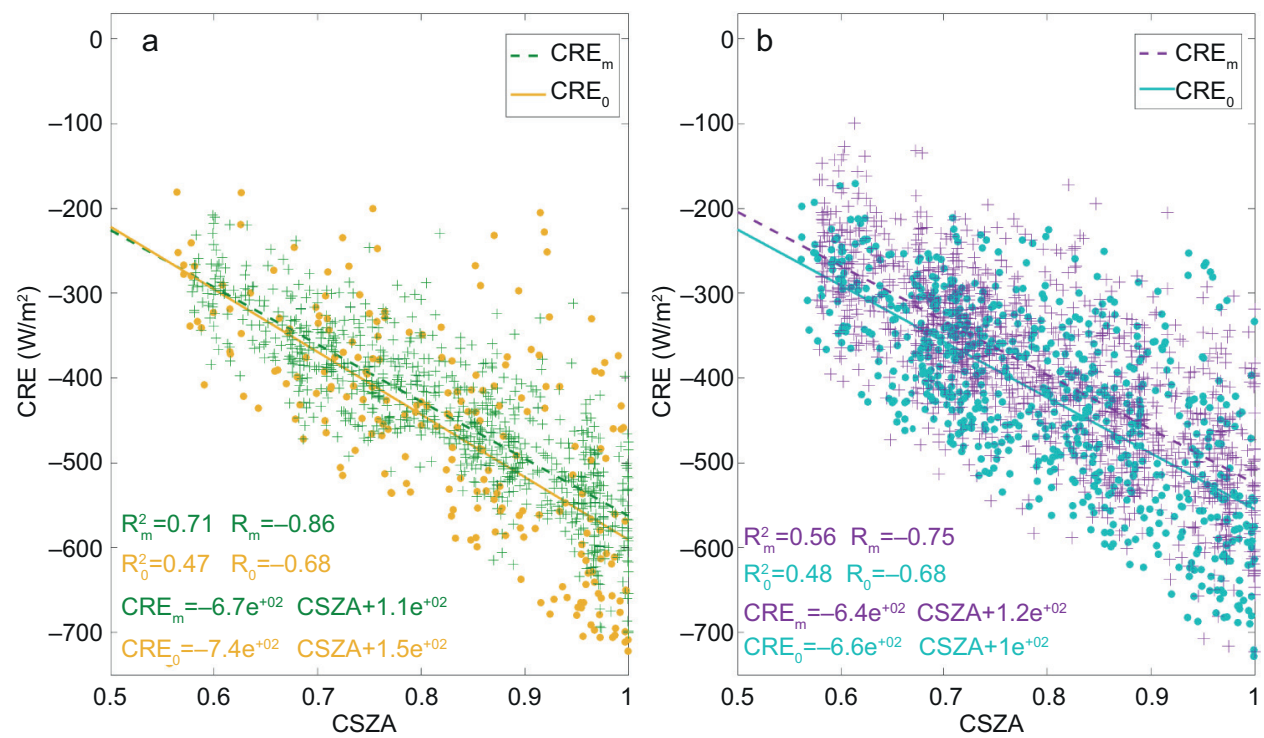

Fig. 4. Relation between CRE (for both $\mathrm{CRE}_{\mathrm{m}}$ and $\mathrm{CRE}_{0}$ ) and CSZA for (a) $\mathrm{Cu}$ and (b) $\mathrm{Sc}-\mathrm{Cu}$. (CRE: cloud radiative effect at the surface; $\mathrm{CRE}_{\mathrm{m}}$ : $\mathrm{CRE}$ from actinometric measurements; $\mathrm{CRE}_{0}$ : modeled CRE; CSZA: cosine of solar zenith angle; $\mathrm{Cu}$ : cumulus; Sc-CU: stratocumulus-cumulus).

linearly as CSZA increases (CRE is more negative as CSZA increases). Spearman's correlation coefficient of -0.86 and -0.68 for $\mathrm{CRE}_{\mathrm{m}}$ and $\mathrm{CRE}_{0}$, respectively, confirm the relative high correlation with CSZA. The determination coefficient of 0.7 for $\mathrm{CRE}_{\mathrm{m}}$ is higher than for $\mathrm{CRE}_{0}$.

In the case of $\mathrm{Sc}-\mathrm{Cu}$, Figure $4 \mathrm{~b}$ also shows a decrease of CRE as function of CSZA, with a Spearman's correlation coefficient of -0.75 and -0.68 for $\mathrm{CRE}_{\mathrm{m}}$ and $\mathrm{CRE}_{0}$, respectively. Similar to $\mathrm{Cu}$, the determination coefficient for $\mathrm{Sc}-\mathrm{Cu}$ is 0.56 for $\mathrm{CRE}_{\mathrm{m}}$, higher than for $\mathrm{CRE}_{0}$. Thus, there are similarities in the behavior of CRE respect to CSZA for the two cloud types. The presence of any of these two cloud types obscuring the sun disk strongly decreases the direct sun irradiance, but at near noon (CSZA close to 1), solar irradiance has its maximum, and hence the maximum cloud effect on solar radiation at the surface is present.

\subsection{Relationship between CRE and COD}

CRO is a function of COD, although other dependencies exist, as the one produced by surface albedo (beyond the scope of this study). However, it is not easy to derive an expression from the radiative transfer theory and hence empirical relationships are frequently obtained. The relation between CRE and COD calculated with both methods is shown in Figure 5. CRE is more negative as COD increases, as can be expected. As it was reported in Mateos et al. (2014), there is a linear relation between $\mathrm{CRE}_{0}$ and COD based on the natural logarithm of COD, with a high Spearman's correlation coefficient of 0.73 and 0.69 for $\mathrm{Cu}$ and $\mathrm{Sc}-\mathrm{Cu}$, respectively.

COD and actinometric measurements conducted between the first 12 and 20 minutes of each hour were considered as coincident measurements and used to analyze the relationship between CREm and COD (Fig. 5b). The relation between $\mathrm{CRE}_{\mathrm{m}}$ and $\ln (\mathrm{COD})$ shows a very poor Spearman's correlation coefficient ( 0.2 for both cloud types). Obviously, this is due to the great dispersion of data and the considerable reduction in the number of experimental data (54 and 238 for $\mathrm{Cu}$ and $\mathrm{Sc}-\mathrm{Cu}$, respectively). This poor correlation may be in part attributable to the fact that measurements of COD and irradiances were acquired with instruments of very different characteristics, hence there are time-delays between measurements in spite of the coincidence criterion. The radiometer used in the actinometric station measures basically the diffuse solar irradiance under 

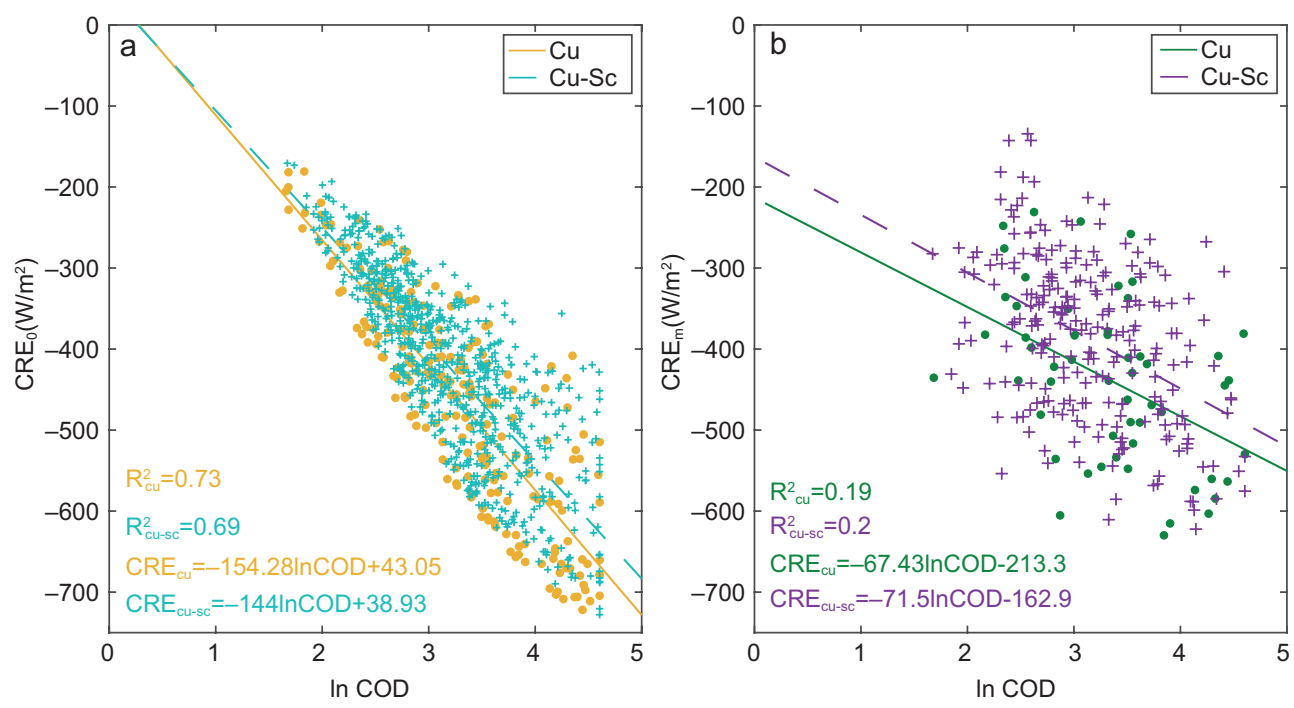

Fig. 5. Relation between (a) $\mathrm{CRE}_{0}$ and $\ln (\mathrm{COD})$ and (b) $\mathrm{CRE}_{\mathrm{m}}$ Vs. $\ln (\mathrm{COD})$. (CRE: cloud radiative effect at the surface; $\mathrm{CRE}_{\mathrm{m}}$ : $\mathrm{CRE}$ from actinometric measurements; $\mathrm{CRE}_{0}$ : modeled CRE; $\mathrm{Cu}$ : cumulus; Sc-CU: stratocumulus-cumulus; lnCOD: natural logarithm of cloud optical depth).

cloudiness conditions, while COD is determined by measuring solar radiation (sky radiance) in the zenith direction. Therefore, the sun-photometer only observes clouds at the zenith.

Table III summarizes the coefficients of the linear regression equation for the $\mathrm{CRE}_{0}-\ln (\mathrm{COD})$ relation in several CSZA ranges. It shows the slope of the fitted line (m), the intersection with the ordinate (n), the determination coefficient $\left(\mathrm{R}^{2}\right)$ and the number of data in the range $\left(\mathrm{N}_{0}\right)$. Linear relations between CRE and $\ln (\mathrm{COD})$ have a high determination coefficient $\left(\mathrm{R}^{2}>0.85\right)$ for all intervals.

\subsection{Dependence of the cloud effect efficiency (CEE) on CSZA and COD}

The relation of CEE vs. CSZA and COD was analyzed only for $\mathrm{CRE}_{0}$ in different ranges of these variables. Figure 6 shows the CEE behavior in relation to COD in six CSZA ranges (the same than in Table III) for both cloud types. Note that the slope values of $m$ in the selected CSZA ranges do not differ much.

The absolute values of CEE for the two cloud types sharply decrease with the increase of the COD value up to 20. After this value, CEE slowly decreases as COD increases. This behavior is explained by the

Table III. Coefficients $m$ and $n$ of linear correlation $\left[\mathrm{CRE}_{0}=\mathrm{m} \ln (\mathrm{COD})+\mathrm{n}\right]$, determination coefficient $\left(\mathrm{R}^{2}\right)$ and number of data $\left(\mathrm{N}_{\mathrm{o}}\right)$ for $\mathrm{Cu}$ and $\mathrm{Sc}-\mathrm{Cu}$ at six CSZA ranges.

\begin{tabular}{|c|c|c|c|c|c|c|c|c|}
\hline \multirow{2}{*}{ CSZA } & \multicolumn{4}{|c|}{$\mathrm{Cu}$} & \multicolumn{4}{|c|}{$\mathrm{Sc}-\mathrm{Cu}$} \\
\hline & $m$ & $n$ & $\mathrm{R}^{2}$ & $\mathrm{~N}_{\mathrm{o}}$ & $m$ & $n$ & $\mathrm{R}^{2}$ & $\mathrm{~N}_{\mathrm{o}}$ \\
\hline $0.64 \geq \mathrm{CSZA}>0.50$ & -94.7 & -24.7 & 0.96 & 22 & -89.5 & -34 & 0.93 & 72 \\
\hline $0.77 \geq \mathrm{CSZA}>0.64$ & -108.6 & -45.7 & 0.91 & 57 & -104.1 & -44.6 & 0.90 & 259 \\
\hline $0.87 \geq \mathrm{CSZA}>0.77$ & -114.4 & -82.1 & 0.86 & 51 & -131.5 & -9.9 & 0.93 & 177 \\
\hline $0.94 \geq \mathrm{CSZA}>0.87$ & -152.7 & 2.8 & 0.96 & 39 & -149.0 & 5.7 & 0.95 & 103 \\
\hline $0.98 \geq$ CSZA $>0.94$ & -141.9 & -76.9 & 0.93 & 38 & -159.4 & 4.4 & 0.95 & 87 \\
\hline $1 \geq \mathrm{CSZA}>0.98$ & -156.7 & -33.5 & 0.97 & 18 & -143.4 & -69.8 & 0.93 & 34 \\
\hline
\end{tabular}

$\mathrm{Cu}$ : cumulus; Sc-CU: stratocumulus-cumulus; CSZA: cosine of solar zenith angle; $\mathrm{CRE}_{\mathrm{m}}$ : cloud radiative effect at the surface from actinometric measurements; $\mathrm{CRE}_{0}$ : modeled cloud radiative effect at the surface; lnCOD: natural logarithm of cloud optical depth). 

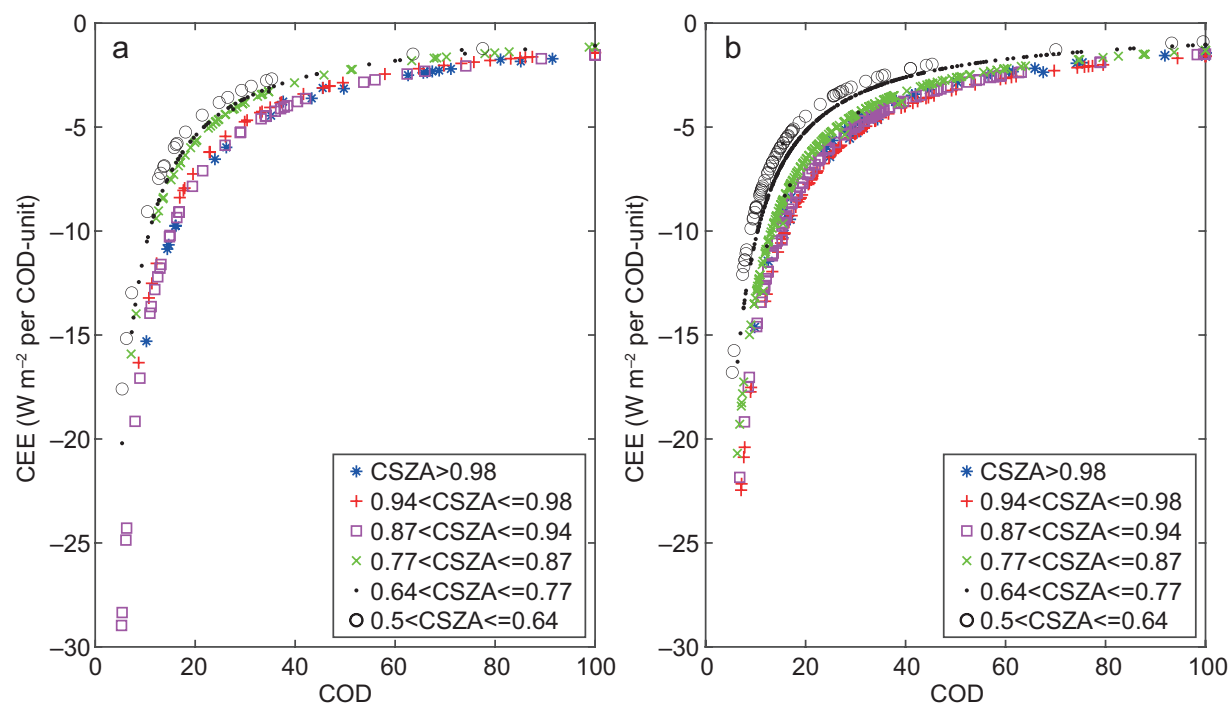

Fig. 6. CEE vs. COD for several CSZA ranges for (a) $\mathrm{Cu}$ and (b) Sc-Cu. (CEE: cloud effect efficiency; COD: cloud optical depth; CSZA: cosine of solar zenith angle; $\mathrm{Cu}$ : cumulus; Sc-CU: stratocumulus-cumulus).

increase of multiple scattering in the clouds with the increase of $\mathrm{COD}$, and saturation as a consequence of the increase of drops overlapping in the cross section (Mateos et al., 2014). Figure 6 also shows that for both cloud types, CEE is less sensitive to changes in COD due to low values of CSZA (lower Sun position).

Figure 7 shows the relation between $\mathrm{CEE}$ and CSZA in four ranges of COD values (5-10, 10-50, $50-75,75-100)$. These ranges were chosen to improve
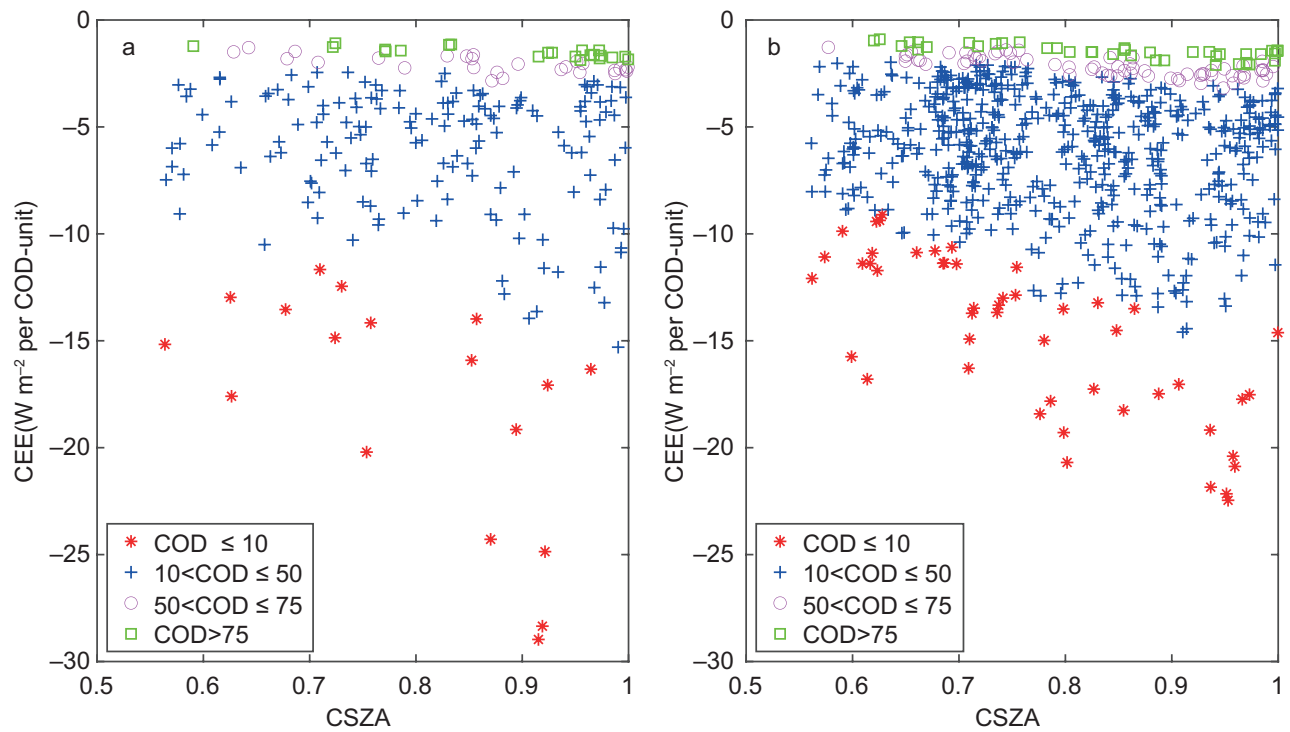

Fig. 7. CEE vs. CSZA at four COD ranges for (a) $\mathrm{Cu}$ and (b) Sc-Cu. (CEE: cloud effect efficiency; CSZA: cosine of solar zenith angle; COD: cloud optical depth; $\mathrm{Cu}$ : cumulus; Sc-CU: stratocumulus-cumulus). 
the understanding of CEE behavior respect to CSZA. In the analysis of both cloud types, the increase of CSZA produces a higher effect per COD unit. This behavior is notable in the range of COD below 10 . The maximum value (in modulus) of $\mathrm{CEE}$ for $\mathrm{Cu}$ is $-29 \mathrm{Wm}^{-2}$ per COD unit with a COD value of 5.3 and CSZA of 0.91 , and the minimum is $-1 \mathrm{Wm}^{-2}$ per COD unit for a COD of 100 and CSZA of 0.72 . Sc-Cu have a maximum value of $-22 \mathrm{Wm}^{-2}$ per COD unit for a COD of 7.1 and CSZA of 0.95 . The minimum value for CEE is $-1 \mathrm{Wm}^{-2}$ per COD unit occurring at a COD of 99.5 (the highest COD value) and CSZA of 0.62 .

\section{Conclusions}

The focus of this paper is to evaluate the clouds radiative effect (CRE) of $\mathrm{Cu}$ and $\mathrm{Sc}-\mathrm{Cu}$ clouds at surface around noon in Camagüey, Cuba. Two methods for the estimation of CRE were applied: (1) using only computations of clear sky irradiances by a 1-D radiative transfer model (RTM) and measurements of irradiances from an actinometric station $\left(\mathrm{CRE}_{\mathrm{m}}\right)$, and (2) computations of both cloudy and clear sky irradiances by the RTM, using cloud optical depth (COD) from a sun-photometer as main cloud input $\left(\mathrm{CRE}_{0}\right)$.

A correspondence criterion between the COD database and the actinometric visual reports of clouds was carried out, in order to assign CODs to a certain cloud type. In addition, a quality control was conducted to remove doubtful COD values to ensure the consistency between the two databases. This quality control consisted in comparing percentages differences between $\mathrm{CRE}_{0}$ and $\mathrm{CRE}_{\mathrm{m}}$ as function of COD. Doubtful COD values appear in a range of 0-5. Once these doubtful COD values were discarded, $\mathrm{CRE}_{\mathrm{m}}$ (experimental data) and $\mathrm{CRE}_{0}$ (theoretical data) values were in better agreement, with the maximum frequency of data in the same range, which enabled the comparison between the two methods for evaluating CRE. After the correspondence criterion and the removing of doubtful values, 255 and 732 $\mathrm{COD}$ values for $\mathrm{Cu}$ and $\mathrm{Sc}-\mathrm{Cu}$ clouds around noon, respectively, were selected.

The Sc-Cu cloud type has its maximum CRE in the range from -300 to $-400 \mathrm{Wm}^{-2}$; for $\mathrm{Cu}$, the maximum was in the interval from -400 to $-500 \mathrm{Wm}^{-2}$. There are no statistically significant differences between both methods for each cloud type.
For $\mathrm{Cu}$ we observed mean values of $\mathrm{CRE}_{\mathrm{m}}$ and $\mathrm{CRE}_{0}$ of -442 and $-460 \mathrm{Wm}^{-2}$, respectively, while for of Sc-Cu they were -390 and $-417 \mathrm{Wm}^{-2}$, respectively. $\mathrm{CRE}_{\mathrm{m}}$ values of the 95 th $(5$ th) percentile were $-603(-292)$ and $-567(-230) \mathrm{Wm}^{-2}$ for $\mathrm{Cu}$ and $\mathrm{Sc}-\mathrm{Cu}$, respectively. Differences between CRE mean values for $\mathrm{Cu}$ and $\mathrm{Sc}-\mathrm{Cu}$ confirm that the latter has less radiative effects in comparison with $\mathrm{Cu}$ at our study site. There are statistically significant differences at the $95 \%$ confidence level between CRE for $\mathrm{Cu}$ and $\mathrm{Sc}-\mathrm{Cu}$ with both computing methods.

A linear decrease of CRE vs. $\ln (\mathrm{COD})$ with a high correlation was found for $\mathrm{CRE}_{0}$. No linear correlation was found between $\mathrm{CRE}_{\mathrm{m}}$ and $\ln (\mathrm{COD})$ because of the lower number of experimental points and their high dispersion due to radiation enhancement effects and also to the fact that measurements of COD and solar irradiance were acquired from instruments with different characteristics, thus having a high time-delay between them.

Cloud effect efficiency (CEE) and its relation with the cosine of the solar zenithal angle (CSZA) and COD were analyzed. The maximum CEE value for $\mathrm{Cu}(\mathrm{Sc}-\mathrm{Cu})$ was $-29(-22) \mathrm{Wm}^{-2}$ per COD-unit, with corresponding values of COD of 5.3 (7.1) and CSZA of $0.91(0.95)$. On the other hand, the minimum value of $\mathrm{CEE}$ for $\mathrm{Cu}(\mathrm{Sc}-\mathrm{Cu})$ was -1 $\mathrm{Wm}^{-2}$ per COD unit with a COD of $100(99.5)$ and CSZA of 0.72 (0.62). CEE values for both cloud types, $\mathrm{Sc}-\mathrm{Cu}$ and $\mathrm{Cu}$, show a clear dependency with CSZA and COD, decreasing in absolute value with increasing COD.

The results obtained in this research improve the understanding of the relationship between low clouds and solar radiation, which is of great importance for climate studies. Sc and $\mathrm{Cu}$ clouds reflect much of the incoming shortwave radiation in the Earth. These low cloud types are the most frequent in our region; they have a great importance in the interaction with irradiances reaching the surface and are related to temperature and further development of other cloud types.

Due to the short period covered by experimental data, it was only possible to evaluate the theoretical method for CEE. However, for the first time, CEE was analyzed as a function of SZA and COD for two different cloud types that have a high occurrence and a great effect on solar radiation in the region. 


\section{Acknowledgments}

Authors from GOAC-INSMET want to thank the GOA-UVA team for their support and logistics. Our gratitude to AERONET NASA and RIMA networks for including the Camagüey site in AERONET. Authors want to acknowledge the anonymous referees that helped to improve the quality of the manuscript.

This work has been supported by the Cuban National Climate Change Research Program under the contract number 01301204 and by the Collaboration Agreement between the Atmospheric Optics Group (GOA-UVA) and the Atmospheric Optics Group of Camagüey (GOAC-INSMET). Partial financial support from GOA-UVA was provided by Spanish projects from MINECO and MICCIN from 2015 to 2021 (CMT2015-66742-R, RTI2018-097864-B-I00) and by ACSUCYL (Junta de Castilla y León) (projects VA100P17 and VA227P20). Partial financial support from FONDECYT 11181335 was provided to principal author Boris Barja.

Analyses used in this study relates with MODIS data were produced with the Giovanni online data system, developed and maintained by NASA GES DISC. Authors also acknowledge the MODIS mission scientists and associated NASA personnel for the production of data used in this research effort.

\section{References}

Ackerman SA, Stephens GL. 1987. The absorption of solar radiation by clouds droplets: An application of anomalous diffraction theory. Journal of the Atmospheric Sciences 44, 1574-1588. https://doi.org/10.1175/152 0-0469(1987)044<1574:TAOSRB >2.0.CO;2

Allan JD, Baumgardner D, Raga GB, Mayol-Bracero OL, Morales-García F, García-García F, Montero-Martínez G., Borrmann S, Schneider J, Mertes S, Walter S, Gysel M, Dusek U, Frank GP, Kramer M. 2008. Clouds and aerosols in Puerto Rico-A new evaluation. Atmospheric Chemistry and Physics 8, 1293-1309. https:// doi.org/10.5194/acp-8-1293-2008

Antuña-Marrero JC, Fonte A, Estevan R, Barja B, Acea R, Antuña-Sánchez JC. 2008. Solar radiation data rescue at Camagüey, Cuba. Bulletin of the American Meteorological Society 89, 1507-1511, https://doi. org/10.1175/2008BAMS2368.1

Antuña-Marrero JC, Cachorro V, García F, de Frutos A, Rodríguez A, Mateos D, Estevan R, Toledano C. 2018.
Comparison of aerosol optical depth from satellite (MODIS), sun photometer and broadband pyrheliometer ground-based observations in Cuba. Atmospheric Measurement Techniques 11, 2279-2293. https://doi. org/10.5194/amt-11-2279-2018

Antuña-Marrero JC, García F, Estevan R, Barja B, Sánchez-Lorenzo A. 2019. Simultaneous dimming and brightening under all and clear sky at Camagüey, Cuba (1981-2010). Journal of Atmospheric and Solar-Terrestrial Physics 190, 45-53. https://doi.org/10.1016/j. jastp.2019.05.004

Barnes WL, Pagano TS, Salomonson VV. 1998. Prelaunch characteristics of the moderate resolution imaging spectroradiometer (MODIS) on EOS-AM1. IEEE Transactions on Geoscience and Remote Sensing 36, 1088-1100. https://doi.org/10.1109/36.700993

Barja B, Antuña-Marrero JC. 2008. Numerical simulation of cirrus cloud radiative forcing using lidar backscatter data. Preliminary results. Óptica Pura y Aplicada 41, 89-95.

Barja B, Antuña-Marrero JC. 2010. Cirrus clouds physical and spatiotemporal features in the Wider Caribbean. Atmósfera 23, 185-196.

Barja B, Antuña-Marrero JC. 2011. The effect of optically thin cirrus clouds on solar radiation in Camagüey, Cuba. Atmospheric Chemistry and Physics 11, 86258634. https://doi.org/10.5194/acp-11-8625-2011.

Barja B, Bennouna Y, Toledano C, Antuña-Marrero JC, Cachorro V, Hernández C, de Frutos A, Estevan R. 2012. Cloud optical depth measurements with the sun-photometer in Camaguey, Cuba. Optica Pura y Aplicada 45, 389-396. https://doi.org/10.7149/ opa.45.4.389

Berg LK, Kassianov EI, Long CN, Mills DL Jr. 2011. Surface summertime radiative forcing by shallow cumuli at the Atmospheric Radiation Measurement Southern Great Plains site, Journal of Geophysical Research: Atmospheres 116, D01202. https://doi.org/10.1029/ 2010JD014593

Boucher O, Randall D, Artaxo P, Bretherton C, Feingold G, Forste P, Kerminen VM, Kondo Y, Liao H, Lohmann U, Rasch P, Satheesh SK, Sherwood S, Stevens B, Zhang XY. 2013. Clouds and aerosols. In: Climate Change 2013: The Physical Science Basis. Contribution of Working Group I to the Fifth Assessment Report of the Intergovernmental Panel on Climate Change (Stocker TF, Qin D, Plattner GK, Tignor M, Allen SK, Boschung J, Nauels A, Xia Y, Bex V, Midgley PM, 
Eds.). Cambridge University Press, Cambridge, United Kingdom and New York, NY, USA. 571-657, https:// doi.org/10.1017/CBO9781107415324.016

Chen T, Rossow WB, Zhang Y. 2000. Radiative effects of cloud-type variations. Journal of Climate 13, 264-286. https://doi.org/10.1175/1520-0442(2000)013<0264:R EOCTV $>2.0 . \mathrm{CO} ; 2$

Chervyakov MY, Neishtadt JA. 2018. Actinometric methods of measurements. Textbook for students of the Faculty of Geography. Saratov Publishing house of the Saratov State University, Russia, 42 pp. (in Russian).

Chiu JC, Huang CH, Marshak A, Slutsker I, Giles DM, Holben BN, Knyazikhin Y, Wiscombe WJ. 2010. Cloud optical depth retrievals from the Aerosol Robotic Network (AERONET) cloud mode observation. Journal of Geophysical Research 115, D14202. https://doi. org/10.1029/2009JD013121

Chou MD, Zhao W. 1997. Estimation and model validation of surface solar radiation and cloud radiative forcing using TOGA COARE measurements. Journal of Climate 10, 610-620. https://doi.org/10.1175/1520-0442 (1997)010<0610:EAMVOS $>2.0 . C O ; 2$

Dolinar EK, Dong X, Xi B, Jiang J, Loeb N, Campbell J, Su H. 2019. A global record of single-layered ice cloud properties and associated radiative heating rate profiles from an A-Train perspective. Climate Dynamics 53, 3069-3088. https://doi.org/10.1007/ s00382-019-04682-8

Eerme K, Aun M. 2012. A review of the variations of optical remote sensing conditions over Estonia in 1958-2011. International Journal of Remote Sensing Applications 2, 12-19.

Freidenreich SM, Ramaswamy V. 1999. A new multiple-band solar radiative parameterization for general circulation models. Journal of Geophysical Research 104, 31389- 31409. https://doi.org/10.1029/ 1999JD900456

Freidenreich SM, Ramaswamy V. 2005. Refinement of the geophysical fluid dynamics laboratory solar benchmark computation and improved parameterization for climate models. Journal of Geophysical Research 110, D17105. https://doi.org/10.1029/2004JD005471

Freidenreich SM, Ramaswamy V. 2011. Analysis of the biases in the downward shortwave surface flux in the GFDL CM2.1 general circulation model. Journal of Geophysical Research 116, D08208. https://doi. org/10.1029/2010JD014930
Gueymard CA. 2017. Cloud and albedo enhancement impacts on solar irradiance using high-frequency measurements from thermopile and photodiode radiometers. Part 1: Impacts on global horizontal irradiance. Solar Energy 153, 755-765. https://doi.org/10.1016/j. solener.2017.05.004

Ham S, Kato S, Rose F, Winker D, L'Ecuyer T, Mace G, Painemal D, Sun-Mack S, Chen Y, Miller WF. 2017. Cloud occurrences and cloud radiative effects (CREs) from CERES-CALIPSO-CloudSat-MODIS (CCCM) and CloudSat radar-lidar (RL) products. Journal of Geophysical Research 122, 8852-8884. https://doi. org/10.1002/2017JD026725

Holben BN, Eck TF, Slutsker I, Tanré D, Buis JP, Setzer A, Vermote E, Reagan JA, Kaufman YJ, Nakajima T, Lavenu F, Jankowiak I, Smirnov A. 1998. AERONET - A federated instrument network and data archive for aerosol characterization. Remote Sensing of Environment 66, 1-16. https://doi.org/10.1016/ S0034-4257(98)00031-5

Kim BG, Schwartz SE, Miller MA, Min Q. 2003. Effective radius of cloud droplets by ground-based remote sensing: Relationship to aerosol. Journal of Geophysical Research 108, 4740. https://doi.org/10.1029/ 2003JD003721.

L'Ecuyer TS, Wood NB, Haladay T, Stephens GL, Stackhouse PWJr. 2008. Impact of clouds on atmospheric heating based on the R04 Cloudsat fluxes and heating rates data set. Journal of Geophysical Research 113, D00A15. https://doi.org/10.1029/2008JD009951

Li J, Yi Y, Minnis P, Huang J, Yan H, Ma Y, Wang W, Ayers J. 2011. Radiative effect differences between multi-layered and single-layer clouds derived from CERES, CALIPSO, and CloudSat data. Journal of Quantitative Spectroscopy and Radiative Transfer 112, 361-375. https://doi.org/10.1016/J.JQSRT.2010.10.006

Li Z, Trishchenko AP. 2001. Quantifying uncertainties in determining SW cloud radiative forcing and cloud absorption due to variability in atmospheric conditions. Journal of the Atmospheric Sciences 58, 376-389. https://doi.org/10.1175/1520-0469(2001)058<0376: QUIDSC $>2.0 . C O ; 2$

Liou KN. 1986. Influence of Cirrus Clouds on Weather and Climate Processes: A Global Perspective. Monthly Weather Review 114, 1167-1199. https://doi.org/10.11 75/1520-0493(1986)114\%3C1167:IOCCOW\%3E2.0. $\mathrm{CO} ; 2$ 
Martínez E, Pomares I. 2002. Evaluation of the solar radiation transmission in clouds from measurements in Havana (in Spanish). In: Proceedings of the first workshop Physics in Meteorology. Havana, Cuba, February 4-6.

Mateos D, Antón M, Valenzuela A, Cazorla A, Olmo FJ, Alados-Arboledas L. 2014. Efficiency of clouds on shortwave radiation using experimental data. Applied Energy 113, 1216-1219. http://dx.doi.org/10.1016/j. apenergy.2013.08.060

McBride PJ, Schmidt KS, Pilewskie P, Kittelman AS, Wolfe DE. 2011. A spectral method for retrieving cloud optical thickness and effective radius from surface-based transmittance measurements. Atmospheric Chemistry and Physics 11, 7235-7252, https://doi. org/10.5194/acp-11-7235-2011.

McClatchey RA, Fenn RW, Selby JE, Volts FE, Garing JS. 1972. Optical properties of the atmosphere. 3rd ed. Air Force Cambridge Research Labs, Hanscom, MA. Available at: https://apps.dtic.mil/sti/pdfs/AD0753075. pdf (accessed on January 25, 2021).

McFarlane S, Long CN, Flaherty J. 2012. A climatology of surface cloud radiative effects at the ARM tropical western Pacific sites. Journal of Applied Meteorology and Climatology 52, 996-1031. https://doi. org/10.1175/JAMC-D-12-0189.1

Mitchell DL, Finnegan W. 2009. Modification of cirrus clouds to reduce global warming. Environmental Research Letters 4, 045102. https://doi.org/10.1088/17489326/4/4/045102

Neiburger M. 1949. Reflection, absorption, and transmission of insolation by stratus cloud.

Journal of the Atmospheric Sciences 6, 98-104. https:// doi.org/10.1175/1520-0469(1949)006<0098:RAA$\mathrm{TOI}>2.0 . \mathrm{CO} ; 2$

Ross YK, Ashcheulov SV, Mikhailov VV. 1969. 2. Methods of actinometric measurements. International Geophysics 12, 49-83. https://doi.org/10.1016/S00746142(08)62774-6

Schiffer RA, Rossow WB. 1983. The International Satellite Cloud Climatology Project (ISCCP): the first project of the World Climate Research Programme. Bulletin of the American Meteorological Society 64. 779-784. https://doi.org/10.1016/0169-8095(88)90026-9

Slingo A. 1989. A GMC Parameterization for the shortwave radiative properties of water clouds. Journal of Atmospheric Sciences 46, 1419-1427. https://doi.org/1 0.1175/1520-0469(1989)046<1419:AGPFTS $>2.0 . C O ; 2$
Spiegel JK, Buchmann N, Mayol-Bracero OL, Cuadra-Rodriguez LA, Valle-Díaz CJ, K. Prather A, Mertes S, Eugster W. 2014. Do cloud properties in a Puerto Rican tropical montane cloud forest depend on occurrence of long-range transported African dust? Pure Applied Geophysics 171, 2443-2459. https://doi.org/10.1007/ s00024-014-0830-y

Stephens GL. 2005. Cloud feedbacks in the climate system: A critical review. Journal of Climate 18, 237-273. https://doi.org/10.1175/JCLI-3243.1

Stephens GL, Vane DG, Tanelli S, Im E, Durden S, Rokey M, Reinke D, Partain P, Mace GG, Austin L, L'Ecuyer T, Haynes J, Lebsock M, Suzuki K, Waliser D, Wu D, Kay J, Gettelman A, Wang Z, Marchand R. 2008. CloudSat mission: Performance and early science after the first year of operation. Journal of Geophysical Research 113, D00A18, https://doi.org/10.1029/ 2008JD009982

Winker DM, Hunt WH, McGill MJ. 2007. Initial performance assessment of CALIOP. Geophysical Research Letters 34, L19803., https://doi. org/10.1029/2007GL030135

Wielicki BA, Barkstorm BR, Harrison EF, Lee III RB, Smith GL, Cooper JE. 1996. Clouds and the Earth's radiant energy system (CERES): An Earth observing system experiment. Bulletin of the American Meteorological Society 77, 853-868. https:// doi.org/10.1175/1520-0477(1996)077<0853:CATERE $>2.0 . \mathrm{CO} ; 2$

WMO. 2017. International cloud atlas: Manual on the observation of clouds and other meteors. WMO No. 407. Secretariat of the World Meteorological Organization, Geneva, Switzerland. Available at: https://cloudatlas. wmo.int/home.html (accessed on November, 2020).

Yanishevsky YD. 1957. Aktinometricheskie pribory i metody nablyudenij (Actinometric receivers and measurement methods). Gidrometeorol. Izd., Leningrad, Russia, 416 pp. (in Russian).

Zhang G, Xu L, Chen H. 1995. A new parameterization for shortwave radiative properties of water clouds. Journal of Applied Meteorology 34, 101-106. https:// doi.org/10.1175/1520-0450-34.1.101 